\title{
Three states of stromal cells-solid, liquid, and aerosol-and innovative delivery methods not previously reported
}

\author{
Hasim Eray Copcu \\ Department of Aesthetic Plastic Surgery, Mest Health Services, Izmir, Turkey
}

Clinical applications of stromal cells obtained mechanically from adipose tissue are quite popular methods. However, generally accepted protocols still do not exist. In this study, three new delivery methods using different protocols are presented as innovative methods in accordance with an approach called "Indication-based protocols." In mechanical methods, before cutting the fat tissue with ultra-sharp blades, which we define as "Adinizing," mixing it with different liquids such as saline or plasma provides the stromal cells in liquid form with high number and viability as a final product. At the same time, since stromal cells and extracellular matrix are preserved by mechanical methods, it was deemed appropriate to use the term total stromal cells (TOST) instead of stromal vascular fraction for this final product, unlike the product obtained with the enzyme. TOST can be combined with plasma and used for dermal filling in "solid" form. In addition to this filling effect, it will also cause a change in the tissue regeneratively. Finally, the stromal cells obtained from liquid can be applied clinically in aerosol form with the help of nebulizer. We believe that three innovative delivery methods can be used successfully in the treatment of many clinical situations in the future.

Keywords Stromal cells / Stromal vascular fraction / COVID-19 / Adipocyte / Fibrin
Correspondence: Hasim Eray Copcu Department of Aesthetic Plastic Surgery, Mest Health Services, Folkart Times Ofis 1. Blok, 602, 296 sok. No:8 Bornova, Izmir 35100, Turkey Tel: +90-232-4646378

Fax: +90-532-2434342

E-mail: ecopcu@gmail.com

@

This article was presented at PRS Korea 2020 on November 13, 2020.

\section{INTRODUCTION}

Stromal cells obtained mechanically from adipose tissue have many advantages over those extracted with enzymatic methods. Beyond being faster, easier, and cheaper, the lack of restrictive regulations imposed by organizations has contributed to increasing interest in developing new methods and devices in this regard [1]. The goal of collecting stromal cells mechanically is to obtain "nanofat"-a semi-solid product in the form of emulsified fat-but the "stromal cell cocktail" obtained as the final prod- uct of the standard enzymatic method, called the stromal vascular fraction (SVF), is in liquid form. Although variations of nanofat are defined with different terms, such as cell aggregate or SVF gel, they are generally solid products in a very thin fat format. Today, nanofat, the "veteran" of mechanical methods, is applied clinically for many different indications, and with such a wide range of applications, there is a need for an end product available in various physical forms $[2,3]$. Copcu and Oztan defined a new technique and achieved high viability and cell count in stromal cell recovery by separating the bonds between paren- 
chymal and stromal cells mechanically instead of with enzymes, using especially sharp blades [1]. Adinizing is the name given to cutting fat tissue using ultra-sharp blades. Copcu and Oztan [1] obtained the stromal cell with high viability and cell number from the adipose tissue mechanically with the adinizing process and named this process MEST (mechanical stromal-cell transfer). These authors, with the indication-based protocols (IPs) they defined, ensured that the final product stromal cells were in the desired physical structure in liquid or solid form (Table 1). The stromal cell can be obtained in liquid form when the condensed fat tissue is mixed with saline or similar liquid before adinizing (pre-adinizing) and then cut with ultra-sharp blades. Since the SVF term belongs to the final product in liquid form obtained with enzymatic products, and extracellular matrix and stromal cells are protected in mechanical methods, they call it total stromal cells (TOST) [4]. Stromal cells are generally applied to target tissue at the time of injection. However, this use is in the form of an emulsified fat graft. Different from all these, Verpaele et al. [5] presented the application of nanofat to the skin by needling as a new application technique. The stromal cell preparation used was in a semi-solid, emulsified fat state. In the same publication, they also reported the application of a "nanofat cream" they produced after the process [5]. Similarly, Cohen et al. [6] applied millifat as biocream. In this study, three application methods are presented as new innovative approaches (Fig. 1), all of which are obtained mechanically and have not been reported before.

\section{IDEA}

This study is a pre-clinic study showing three new and different application possibilities of stromal cells, and 21 separate trials were conducted according to the standards of good medical practice (ICH-E6) and the principles of the Declaration of Helsinki. All patients were provided detailed information preoperatively and gave written consent for all surgical procedures, anesthesia, intraoperative video recording, and photography. In addition, a written consent form was obtained from the patients stating that they willingly donated their adipose tissue for laboratory analysis. In this study, a patented $\mathrm{CE}$ (European Conformity) marking and ISO 13485 certified blade system was used, and rules of minimal manipulation were followed. No enzymes and similar chemicals were used, and the structure of the fat tissue was not altered.

In this study, stromal cells were obtained from adipose tissue in liquid or solid form in accordance with the technique called
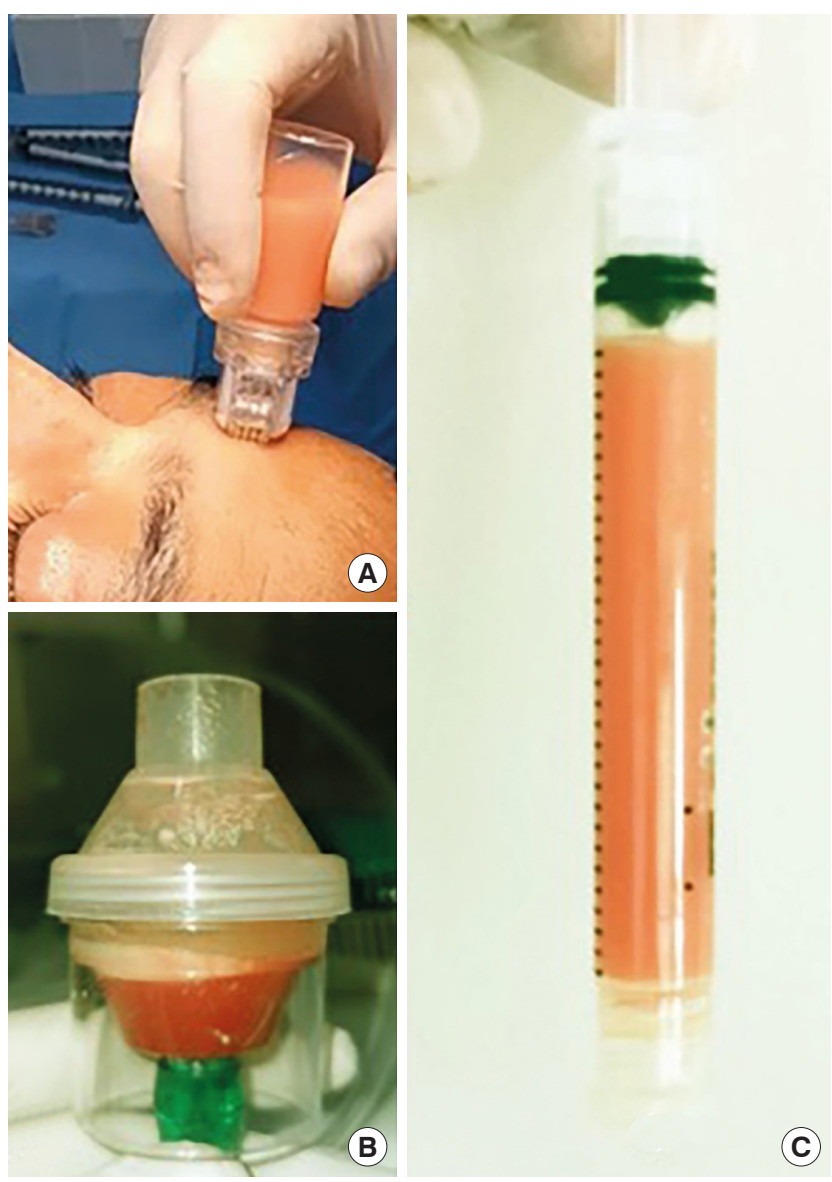

Fig. 1. View of three states of stromal cells by mechanical extraction technique. (A) A photograph of the hydra-roller with TOST (liquid state). (B) View of the nebulizer collection unit with TOST (aerosol state). (C) A photograph of the TOST gel with plasma (solid state). TOST, total stromal cells.

Table 1. Summary of IPs, adinizing: cutting of the fat tissue with ultra-sharp blades, TOST

\begin{tabular}{|c|c|c|c|c|c|c|}
\hline \multirow{2}{*}{ IPs No. } & \multirow{2}{*}{$\begin{array}{l}\text { Total volume } \\
\quad(\mathrm{mL})\end{array}$} & \multirow{2}{*}{$\begin{array}{l}\text { Condensed fat volume } \\
\text { (after 1st centrifuge } \\
500 \mathrm{~g}, 2 \mathrm{~min} \text { ) (mL) }\end{array}$} & \multirow{2}{*}{$\begin{array}{l}\text { Pre-adinizing saline } \\
\text { or plasma volume } \\
(\mathrm{mL})\end{array}$} & \multirow{2}{*}{$\begin{array}{c}\text { Adinizing } \\
2,400,1,200,600,400 \mu \mathrm{m} \\
\text { ultra-sharp blades } \\
\text { (25 pass/each) }\end{array}$} & \multicolumn{2}{|c|}{ After second centrifuge at $1,200 \mathrm{~g}(5 \mathrm{~min})$} \\
\hline & & & & & TOST type & TOST volume (mL) \\
\hline 1 & 10 & 5 & 5 & + & Solution & $5-6$ \\
\hline 2 & 20 & 10 & 10 & + & Solution & $8-12$ \\
\hline 3 & 10 & 10 & 0 & + & Gel/dense solution & $1-2$ \\
\hline 4 & 20 & 20 & 0 & + & Gel/dense solution & $3-4$ \\
\hline
\end{tabular}

IPS, indication-based protocols; TOST, total stromal cells. 
MEST described by Copcu and Oztan [1]. Under local anesthesia, $5 / 10 \mathrm{~mL}$ of adipose tissue according to the IPs was harvested from abdominal area with 3-mm diameter 4-hole cannula and then centrifuged at a speed of $500 \mathrm{~g}$ for 2 minutes and condensed fat was obtained by discarding tumescent fluid and blood elements. Then, adinizing process was performed with 2,400 $\mu \mathrm{m}, 1,200 \mu \mathrm{m}, 600 \mu \mathrm{m}$, and finally $400 \mu \mathrm{m}$ diameter ultrasharp blades (Adinizer; BSL-rest, Seoul, Korea), with 25 back and forth movements between two injectors. Finally, stromal cells were obtained by centrifugation at $1,200 \mathrm{~g}$ for 5 minutes.

\section{Solid: mechanical stromal-cell gel}

TriCell PRP kit (Rev-Med Inc., Seongnam, Korea) was used to obtain platelet-poor plasma (PPP). Twenty-seven milliliters of venous blood was mixed with $3 \mathrm{~mL}$ citrate. It was first centrifuged at 3,200 rpm for 4 minutes and then at 3,300 rpm for 3 minutes and after the second centrifuge, the PPP in the second chamber of kit was automatically obtained. PPP gel machine was used to put the stromal cells into gel form (Rejuvenation gel maker, Rev-Med Inc.). In this method, $5 \mathrm{~mL}$ condensed fat was mixed with $5 \mathrm{~mL}$ PPP and the TOST obtained at the bottom after the adinizing process is transferred to 3- $\mathrm{mL}$ injectors. The gel machine provided stromal gel production by gradual cooling for 10 minutes to $28^{\circ} \mathrm{C}$, after 10 minutes of gradual heating to $100^{\circ} \mathrm{C}$ (Supplemental Video 1).

\section{Liquid: stromal-cell application in liquid form with hydro-roller}

Ten milliliters of condensed fat was mixed with $10 \mathrm{~mL}$ saline and adinized as described before. TOST in liquid form obtained is easily placed in the $10-\mathrm{mL}$ chamber of the hydra-roller device ( $1 \mathrm{~mm}$ microneedles) and can be applied to the entire face, hand, or low-necked areas by roller application on the skin surface. Penetration is greater and faster due to its liquid form (Supplemental Video 2).

\section{Aerosol: stromal cell application with nebulizer}

The TOST obtained is placed in the 8-mL chamber of the neb- ulizer, and TOST in aerosol form is achieved to reach the planned target (Supplemental Video 3).

Stromal cells were collected in a container and re-analyzed in each status.

Total viable nucleated cell recovery and viability percentage were determined using the LunaStem Automated Fluorescence Cell Counter device (Logos Biosystems, Anyang, Korea) with acridine orange/propidium iodide stain in each delivery methods before and after of processes.

\section{Results}

Each new delivery method was tested in 20 different cases and the average of the obtained results is presented in Table 2.

\section{DISCUSSION}

This innovative delivery method may be a very important approach. Copcu $[7,8]$ stated that stromal cells could potentially be used in the treatment of coronavirus disease 2019 (COVID-19) and similar conditions. It has been reported that it can potentially be used in prevention, treatment, and sequelae repair. Its use in aerosol form with the nebulizer may create an alternative route for stromal cell administration in future COVID19-like situations. However, further studies are required in this regard.

In this study, as innovations and ideas, stromal cells obtained mechanically from adipose tissue are presented in three forms that have not been previously reported. Their clinical significance and results should be evaluated in further studies. The possibility of applying stromal cells as solids could create an important alternative for dermis, such as hyaluronic acid. Being autogenous will prevent complications due to filling and provide tissue regeneration as well as filling in the stromal cells it contains. Simultaneous application of liquid stromal cells with hydro-roller can provide the desired results with both the physical effects and healing and the restorative effects of stromal cells, which will provide a synergistic effect [9]. Although Zimmerlin et al. [10] described intra-tracheal route of stromal cells com-

Table 2. Effectiveness of TOSTs in different physical states

\begin{tabular}{|c|c|c|c|c|c|c|c|c|c|}
\hline \multirow[b]{2}{*}{ States } & \multirow{2}{*}{$\begin{array}{l}\text { No. of } \\
\text { cases }\end{array}$} & \multirow{2}{*}{$\begin{array}{l}\text { Condensed fat } \\
\qquad(\mathrm{mL})\end{array}$} & \multirow[b]{2}{*}{ Pre-dilution } & \multicolumn{3}{|c|}{ Pre-applıcatıon } & \multicolumn{3}{|c|}{ Post-applıcatıon } \\
\hline & & & & $\begin{array}{c}\text { TOST volume (mL), } \\
\text { mean } \pm S D\end{array}$ & $\begin{array}{c}\text { TNC }\left(\times 10^{6}\right) \text {, } \\
\text { average }\end{array}$ & $\begin{array}{l}\text { Viability, } \\
\text { mean } \pm \text { SD }\end{array}$ & $\begin{array}{c}\text { TOST volume (mL), } \\
\text { mean } \pm S D\end{array}$ & $\begin{array}{l}\text { TNC }\left(\times 10^{6}\right), \\
\text { average }\end{array}$ & $\begin{array}{l}\text { Viability, } \\
\text { mean } \pm \text { SD }\end{array}$ \\
\hline Solıd & 7 & 5 & Plasma & $4.8 \pm 0.6$ & 3.7 & $94 \pm 2$ & $3.6 \pm 0.4$ & 3.0 & $86 \pm 2$ \\
\hline Liquid & 7 & 5 & Saline & $4.1 \pm 0.4$ & 3.2 & $91 \pm 2$ & $3.9 \pm 0.4$ & 2.9 & $88 \pm 2$ \\
\hline Aerosol & 7 & 10 & Saline & $8.4 \pm 0.5$ & 3.1 & $91 \pm 2$ & $7.8 \pm 0.3$ & 2.7 & $81 \pm 2$ \\
\hline
\end{tabular}

Comparison of average cell number, viability and volume before and after the procedure. Stromal cells collected after each application procedure were re-evaluated in terms of both volume, cell number and viability.

TOST, total stromal-cells; TNC, total nucleated cells. 
bining with fibrin, the application of fresh mechanical stromal cells in the form of aerosol is a promising new approach.

\section{NOTES}

\section{Conflict of interest}

No potential conflict of interest relevant to this article was reported.

\section{Ethical approval}

The study was approved by the Institutional Review Board of Izmir Hospital (IRB No. 012/21) and performed in accordance with the principles of the Declaration of Helsinki. Written informed consent was obtained.

\section{Patient consent}

The patients provided written informed consent for the publication and the use of their images.

\section{ORCID}

Hasim Eray Copcu https://orcid.org/0000-0003-3799-3504

\section{Supplementary material}

Supplemental Video 1. Solid state of stromal-cells. Supplemental data can be found at: https://doi.org/10.5999/aps.2021.00311. v001.

Supplemental Video 2. Liquid state of stromal-cells. Supplemental data can be found at: https://doi.org/10.5999/aps.2021.00311. v002.

Supplemental Video 3. Gas (aerosol from) state of stromal-cells. Supplemental data can be found at: https://doi.org/10.5999/ aps.2021.00311.v003.

\section{REFERENCES}

1. Copcu HE, Oztan S. New mechanical fat separation technique: adjustable regenerative adipose-tissue transfer (ARAT) and mechanical stromal cell transfer (MEST). Aesthet Surg J Open Forum 2020;2:ojaa035.

2. Tonnard P, Verpaele A, Peeters G, et al. Nanofat grafting: basic research and clinical applications. Plast Reconstr Surg 2013;132:1017-26.

3. Ghiasloo M, Lobato RC, Diaz JM, et al. Expanding clinical indications of mechanically isolated stromal vascular fraction: a systematic review. Aesthet Surg J 2020;40:NP54660.

4. Copcu HE, Oztan S. Not stromal vascular fraction (SVF) or nanofat, but total stromal-cells (TOST): a new definition. systemic review of mechanical stromal-cell extraction techniques. Tissue Eng Regen Med 2021;18:25-36.

5. Verpaele A, Tonnard P, Jeganathan C, et al. Nanofat needling: a novel method for uniform delivery of adipose-derived stromal vascular fraction into the skin. Plast Reconstr Surg 2019;143:1062-5.

6. Cohen SR, Tiryaki T, Womack HA, et al. Cellular optimization of nanofat: comparison of two nanofat processing devices in terms of cell count and viability. Aesthet Surg J Open Forum 2019;1:ojz028.

7. Copcu HE. Potential using of fat-derived stromal cells in the treatment of active disease, and also, in both pre- and postperiods in COVID-19. Aging Dis 2020;11:730-6.

8. Copcu HE. New normal: two aspects of adipose tissue in COVID-19-treat and threat? Expert Opin Biol Ther 2020; 20:1283-92.

9. Doddaballapur S. Microneedling with dermaroller. J Cutan Aesthet Surg 2009;2:110-1.

10. Zimmerlin L, Rubin JP, Pfeifer ME, et al. Human adipose stromal vascular cell delivery in a fibrin spray. Cytotherapy 2013; 15:102-8. 